\title{
CRITICAL SUCCESS FACTORS FOR IMPLEMENTING AN ERP SYSTEM WITHIN UNIVERSITY CONTEXT: CONCEPTS AND LITERATURE REVIEW
}

\author{
Ashwaq AlQashami and Heba Mohammad \\ Al-Imam Muhammad Ibn Saud University, College of Computer and Information \\ Sciences, Information Systems Department, Riyadh, Saudi Arabia
}

\begin{abstract}
Nowadays, Information Technology (IT) plays an important role in efficiency and effectiveness of the organizational performance. As an IT application, Enterprise Resource Planning (ERP) systems is considered one of the most important IT applications because it enables the organizations to connect and interact with its administrative units in order to manage data and organize internal procedures. Many institutions use ERP systems, most notably Higher Education Institutions (HEIs). However, many projects fail or exceed scheduling and budget constraints; the rate of failure in HEIs sector is higher than in other sectors. With HEIs' recent movement to implement ERP systems and the lack of research studies examining successful implementation in HEIs, this paper provides a critical literature review with a special focus on Saudi Arabia. Further, it defines Critical Success Factors (CSFs) contributing to the success of ERP implementation in HEIs. This paper is part of a larger research effort aiming to provide guidelines and useful findings that help HEIs to manage the challenges for ERP systems and define CSFs that will help practitioners to implement them in the Saudi context.
\end{abstract}

\section{KEYWORDS}

Enterprise Resource Planning (ERP) system, ERP implementation, Critical Success Factors (CSFs), Higher Education Institutions (HEIs), Higher Education

\section{INTRODUCTION}

Information Technology (IT) has brought the best products to enrich various aspects of modern life; no organization can be effective without the adoption of the latest available technology. An Enterprise Resource Planning (ERP) system is one of the technologies used for the best running of organizations to attain effectiveness and efficiency. This system has been defined by many researchers as an integrated information system (IS) and a comprehensive software package that integrates and controls all the business processes and functions in an organization to institutionalize the sharing of organizational data resources [ $1,2,3,4]$.

The ERP system consists of software support modules including utilities for marketing and sales, field service, product design and development, production and inventory control, procurement, distribution, industrial facilities management, process design and development, manufacturing, quality, human resources, finance and accounting, and information services[5]. It helps the different departments of an organization to move information among different processes, reduce costs, increase operational efficiencies, improve business process management, facilitate 
communication, share information and knowledge across organizational units, and improve decision making capability [6]. Because of these improved features and through the development of business and administrative procedures, many organizations around the world have implemented or updated their current management IS with an ERP system or are in the process of implementing such a system. Despite all the benefits of these systems, implementation is costly, time consuming and complicated, requiring large investments in the fields of planning, consulting and implementing software projects. About $60-90 \%$ of organizations fail in the implementation of the ERP system[5,7,8], while about $90 \%$ of ERP projects go over time or over budget $[9,10]$. Accordingly, many challenges and obstacles may arise that hinder successful implementation and affect the benefits intended from the system.

The Higher Education Institutions (HEIs) sector is one of the most important sectors seeking to keep pace with technological development and to benefit from ERP systems to accelerate and simplify the management of data and internal procedures while reducing the cost and increasing the efficiency of institutional performance. Unlike business sectors, which seek commercial profit, HEIs belong to the non-profit governmental sector. HEIs spend huge amounts to move to these advanced systems, but many difficulties may arise. Such difficulties often end the process of ERP implementation, resulting in failure because HEIs -as part of the governmental sectorhave a unique nature where administrative structures are inert and employees tend to resist the idea of change. Therefore, HEIs have an urgent need to concentrate on changing the processes prior to implementing the technology. Thus, the role of the top management support is vital for planning and implementing ERP systems, as it is necessary to stimulate the organization and employees before implementation and engage in effective communication with staff to increase the probability of success[11,12].

Previous studies have suggested that ERP software system implementations is complicated and time consuming $[5,7,10,13,14,15]$. In addition, these studies have pointed out that there is no sure method of achieving success in implementing ERP systems; many ERP implementation projects fail or go over time and over budget. It is noteworthy that several previous studies have focused on the implementation of ERP systems in the business sector $[5,15,16,17,18,19,20$, $21,22,23,24]$, but there is lack of studies on implementation in the HEI sector around the world $[25,26,27,28,29]$. Moreover, these studies have argued that the university community needs research attention to achieve more relevant knowledge regarding ERP implementation [26]. Furthermore, there is an urgent need to identify the success factors that lead to the successful implementation of these systems[28], since the failure rate in HEIs is higher than that in the business sector [11 , 30 ]. Moreover, Saudi HEIs are in the early stage of technology development because of the lack of implementation of ERP systems in this country [30, 31]. Therefore, it is crucial to study critical success factors (CSFs) to reduce the failure rate of ERP systems in Saudi HEIs.

\section{DEFINITION OF ERP SYSTEMS}

Several definitions of ERP systems have been offered by a range of authors in the literature. For example, Gable [32] described ERP systems as comprehensive software packages that seek to integrate and automate the complete range of business processes and functions to present a holistic view of the business from a single information and IT architecture. Rosemann and Wiese defined ERP systems as "customizable, standard application software which includes integrated business solutions for the core processes (e.g. production planning and control, warehouse management) and the main administrative functions (e.g. accounting, human resource management) of an enterprise" [33, p. 1]. 
Previously, ERP systems were perceived as integrated software applications that control and manage different departmental functions such as inventory control, accounting, finance, and human resources (HR) in a single centralized system with a common database. Now, ERP II the second generation of ERP systems - has been introduced with advanced features to deal with multiple business units, such as customer relationship management and supply chain management. Moreover, it integrates Internet-enabled applications for e-business, allowing access at anytime and from anywhere. The term ERP evolution is widespread and describes integrated information systems appropriate to any organization, regardless of geographic location and size $[14,34,35]$.

Many researchers have provided broad definitions of ERP systems. However, a recent and comprehensive definition of ERP systems was provided by Beheshti as "a set of business applications or modules, which links various business units of an organization such as financial, accounting, manufacturing, and human resources into a tightly integrated single system with a common platform for flow of information across the entire business. With the use of the Internet as a business medium, organizations can use the expanded version of ERP, ERP II, to connect their internal business systems with the systems of customers and suppliers" [36, pp. 184-185].

Each ERP system contains many different modules referring to business functions such as HR; some business functions have more advanced and powerful modules than others. A typical ERP system may consist of the following software modules: HR Management, Accounting and Finance, Procurement Management, Manufacturing, Distribution and the Supply Chain[37]. Moreover, several vendors offer ERP systems in the marketplace; the top four vendors are SAP, Oracle, Baan, and PeopleSoft [ 21, 38 ].

\section{MOTIVATIONS FOR ADOPTING ERP SYSTEMS AND THEIR BENEFITS}

There are many reasons to adopt ERP systems. It is important for the organization to understand the reasons for deciding to adopt ERP systems so that they can take advantage of the full benefits. The main reasons for implementing an ERP system can be summarized as follows: providing an integrated business computing solution, improving a company's ability to compete in the marketplace, improving business processes and internal efficiency of workflow and reducing the overhead costs in an institution through computerization, enhancing the decision-making process by providing accurate and updated organization-wide information. Improvement in all of these areas will enhance company performance [36, 39, 40, 41, 42].

A comprehensive framework for assessing the benefits of ERP systems has been proposed by Shang and Seddon $[43,44]$. This framework classifies the types of benefits that organizations can obtain by using ERP systems along five dimensions as follows:

- Strategic: Supporting business alliance and business growth, generating product differentiation, and building cost leadership, business innovations, and external linkages with customers and suppliers;

- Operational: Cost and cycle time reduction, quality, productivity and customer service improvement;

- Managerial: Better resource management, improved decision making and planning, and performance improvement;

- IT infrastructure: Building business flexibility for current and future changes, IT cost reduction, and increased IT infrastructural capability; and 
- Organizational: Supporting organizational changes, and facilitating business learning, empowerment, and building a common vision.

Numerous studies [40, 41, 43] have listed the most important attributes of ERP systems and their ability to effectively improve business' organizational processes, including the following:

- Automating, coordinating, and integrating business processes across organizational locations and functions.

- Sharing common data and practices across the whole enterprise to reduce errors.

- Producing, accessing, and managing information in a real-time environment available anywhere and anytime to facilitate rapid and better decision making and cost reductions.

- Providing a user-friendly web interface system to corroborate interactivity, as such an interface can improve integrated portals for an extensive variety of administrative functionalities.

- Enabling effective and useful conduct of a new business process, such ase-government, e-learning, e-commerce, e-procurement and e-portfolio.

\section{CHALLENGES TO ERP IMPLEMENTATION}

Although implementing an ERP system has significant benefits, doing so successfully is a challenge. ERP systems are highly complex and require a comprehensive risk strategy; moreover, they are very costly and have a high failure rate even under ideal circumstances [13]. They often require long implementation times and significant resources [5, 7, 10, 13, 14, 15, 45]. According to Zhang et al. [15] , on average, ERP projects were $178 \%$ over budget, took 2.5 times as long as projected, and delivered only $30 \%$ of the planned benefits. In addition, many barriers appear that affect successful implementation, including substantial organizational problems such as employee resistance to change $[13,24,46]$. Thus, the decision to implement an ERP system is a difficult undertaking for any organization.

Over the years, many companies have implemented ERP systems, but many others have faced implementation failure or ended up going over budget and experiencing delays [14, 38, 47, 48, $49,50]$. Approximately $90 \%$ of ERP projects end up late or over budget $[9,10,13]$. Markus and

Tanis [51] defined success from the viewpoint of managers and implementation consultants as completing the ERP project implementation on time and within budget. Therefore, chief executive officers and senior executive teams must be deeply involved and have a strong commitment to the ERP project to achieve successful implementation [38].

An understanding of the main reasons why many ERP implementation projects have failed could be a recipe for success in a new project. Umble et al. [24] summarized reasons for project failure into 10 categories. They contended that ERP could fail because of a lack of clearly defined strategic goals, lack of commitment of top management, poor project management, resistance to change in the organization, poor selection of an implementation team, lack of data accuracy, inadequate education and training such that users cannot run the ERP system, lack of adaptation of performance measures to ensure that the organization changes, lack of resolution of multi-site issues, and technical complications. In addition, they refer to three main factors that can be responsible for failure of ERP system and these factors are: poor planning or and management, change in business goals during project and lack of business management support. Likewise, Zhang et al. [15] refers to the reasons of problems with the implementation of ERP systems as: need for business process change during the implementation of an ERP system, lack of top management support, data accuracy and user involvement, education and training are frequently 
International Journal of Managing Information Technology (IJMIT) Vol.7, No.4, November 2015

disregard and are given less time due to schedule pressures and less understanding of crossfunctional business processes.

\section{SUCCESS FACTORS FOR ERP IMPLEMENTATION}

The concept of CSFs was developed in the early 1960s. According to Rockart [52], Ronald Daniel first discussed the idea of CSFs in the management literature, stating that information analysis must focus on "success factors" when as a new approach to help achieve organizational goals.

Rockart [52] developed the idea of identifying the CSFs from the viewpoint of chief executives, pointing out that the process of identifying CSFs helps to ensure that these factors receive the necessary attention and are carefully managed by an organization. Rockart defined CSFs as "the limited number of areas in which results, if they are satisfactory, will ensure successful competitive performance for the organization"[52, p.85]. Rockart and Bullen affirmed that "CSFs are the few key areas where 'things must go right' for the business to flourish and for the manager's goals to be attained" [53, p.7]. Meanwhile, Pinto and Slevin described CSFs as "factors which, if addressed, significantly improve project implementation chances" [54, p. 22].

In the ERP context, Rabaa'I defined CSFs as "a set of activities that needs special considerations and continual attention for planning and implementing an ERP system" [28, p. 137]. They have also been defined as "factors needed to ensure a successful ERP project" $[17$, p. 31]. Thus, CSFs are particularly useful, as they provide clear insight and guidance on where to focus special consideration and resources and continual attention in planning for successful ERP project implementation[55].

It is important to improve the implementation success of ERP systems, identify the CSF, and understand the critical factors that constitute successful ERP implementation at each phase [56]. Thus, the critical factors involved in ERP implementation can be given more, and proactive approaches can be developed to counter the high failure rate of ERP implementation [21, 52]. Ultimately, this will enhance the likelihood of achieving higher success levels, cost savings, time savings, quality and efficiency in their ERP system [57].

ERP implementation process has three main stages that are typically for the life cycle of ERP projects: pre-implementation or setting-up phase, implementation and post-implementation or evaluation phase $[58,59,60,61]$. Nevertheless, some researchers considered each stage to be substages according to their perspectives; some of published articles are related only to the ERP implementation phase rather than related to the other ERP phases [59]. Furthermore, Al-Mashari et al. [13], pointed out that ERP projects can be seen as successful according to: (1) Correspondence success: where there is a match between the ERP system and the specific planned objectives of implementation, (2) Process success: when the system is completely implemented within time and budget, (3) Interaction success: when users' attitudes toward ERP system are positive; and (4) Expectation success: where the ERP systems matches users' expectations. However, according to Markus and Tanis an optimal success refers "to the best outcomes the organization could achieve with enterprise systems, gave its business situation, measured against a portfolio of a project, early operational, and longer term business results metrics" [51, p.186]. 
International Journal of Managing Information Technology (IJMIT) Vol.7, No.4, November 2015

\section{OVERVIEW OF THE RESEARCH ON ERP IMPLEMENTATION SUCCESS FACTORS IN ORGANIZATIONS}

Several efforts were made to identify CSFs in the literature, due to the growth and complexity of ERP implementations during the 1990s, to help guide the success implementation of ERP systems in a different business organizations and commercial sector. The results of some major studies related to ERP implementation success factors have been described following review;

Al-Mashari et al. [13] provided a comprehensive taxonomy of ERP system CSFs. The authors identified $12 \mathrm{CSFs}$ and divided them into three groups linked to the stages of an ERP implementation (setting-up, deployment, and evaluation). The factors identified in the Setting-up stage were: management and leadership, visioning and planning. Whereas in Deployment stage: ERP package selection, communication process management, training and education, project management, legacy systems management, system integration, system testing and cultural and structural changes. Finally, evaluation stages identify factor of performance evaluation and management. Moreover, the researchers affirmed and concluded that the most essential factor of successes and the pre-requisite for effective and successful ERP implementation is 'leadership and commitment'.

Zhang et al. [15] developed a comprehensive conceptual framework based on previous studies to identify CSFs for ERP systems implementation and success measures including four main propositions which are: organizational environment, user environment, ERP system environment, ERP vendor environment. Moreover, they discussed the findings of qualitative case studies at four companies which implemented one specific ERP system (Baan IV) in China through conducting interviewees to collect data.

Holland and Light [17] developed a research framework consisting of 12 CSFs based on a review of literature and involved an eight case studies of ERP implementation projects in different companies and industries through conducting the interviews, and they divided the CSFs into strategic (legacy systems, ERP strategy, business vision, top management support, project plans and schedule) and tactical (client consultation, personnel, business process change and software configuration, client acceptance, communication, monitoring and feedback, trouble shooting) factors. The authors emphasized on the importance of managing the gap between their legacy systems and the ERP business processes in organizations, and the importance of selecting an appropriate ERP strategy.

Jafari et al. [18], after reviewing 28 articles identified $10 \mathrm{CSFs}$, that affect implementing ERP system in Malaysian companies and investigated the importance of these factors using questionnaire survey method, which has sent to Chief Information Officers (CIOs), IT managers, Directors of Management Information System (MIS). They found the critical factors are: support from top management, clear goals and objectives, communication, effective project management, business process engineering, data accuracy and integrity, suitability of software and hardware, support from vendor, education and training and user involvement. Where, the extremely important factors for ERP implementation in Malaysia have been shown to be 'top management support' and 'clear goals and objectives'.

Loh and Koh [21] focused on the CSFs for ERP implementations in small and medium-sized enterprises (SMEs) based on a comprehensive literature review and interviews at eight large organizations in UK. They first identified 21 CSFs then they deducted to 11 CSFs on the base of grouping similar factors together. The study found that the discovery and management of critical 
elements (CEs) and their constituents at each phase of the ERP implementation project leads to improve the successful percentage of implementation.

Soja [23] in his research, proposed success model thorough literature review and feedback from ERP adopters that included five success factors for ERP projects implementation were related to the implementation participants, top management involvement, project definition and organization, project status and information systems, as well as those factors containing more than 20 elements. This model was empirically validated on the basis of survey 68 enterprises in Poland from various types of ERP projects which differ in duration time, project scope and company size, from the viewpoint of the 31 ERP experts and 45 people from the companies introduced ERP system to their organizations. Moreover, the results reveal that practitioners whose dealing with ERP project misunderstanding of particular factors importance for the project outcome. Whereas practitioners do not appreciate the significance of particular factors that have an important influence on project success. On the other hand, some factors are overestimated, such as project manager presence.

Umble et al. [24] identified CSFs based on literature review and further applied the factors in an ERP implementation case study. Then, they concluded to nine CSFs which are: clear understanding of strategic goals, commitment by top management, excellent project management, organizational change management, great implementation team, data accuracy, extensive education and training, focused performance measures and multi-sites issues.

Finally, in a research study of Nah, Lau and Kuang [41] present through comprehensive review of the literature $11 \mathrm{CSFs}$ as follow: top management support, ERP teamwork and composition, change management program and culture, project management, business plan and vision, business process reengineering (BPR) with minimum customization, monitoring and evaluation of performance, effective communication, software development, testing and troubleshooting, project champion, appropriate business and IT legacy systems. Then, they classify that the CSFs based on four phases identified by Markus and Tanis [51] an ERP life cycle model (chartering, project, shakedown, onward and upward) according to stages of implementation.

\section{ERP SYSTEM IN HEIS}

Instead of developing an IT system in-house, many local government organizations are turning to commercial off-the-shelf (COTS) ERP systems solutions offered by commercial vendors that support core administrative processes such as budgeting, accounting, procurement, performance, and HR management by integrating the data required for these processes in a single database. This allows them to plan their IT resources more effectively, manage their data and legacy systems, and increase the efficiency of the institutional performance [62]. Recently, ERP systems have been applied to new institutional contexts (i.e., financial services, public sector, healthcare, and higher education). Therefore, the HEI sector as one of the main parts of government has been strongly influenced by global trends to adopt new technologies. HEIs begin implementing ERP systems and replace their old systems to overcome the limitations of legacy systems, support all business functions (administrative, accounting, organizational, etc.), improve their management and administration systems, manage their operations and make them more transparent, and achieve performance improvements.

The investment in ERP systems implementation represents the biggest investment in information and communications technology (ICT) for HEIs [50, 63]. It is tempting to see HEIs as unique institutions [50] ; however, according to Lockwood [64], there are many similarities and differences between HEIs and business organizations, so that the HEIs face many problems common to most modern business corporations, including coordinating resources, stimulating and 
facilitating the enterprise among staff, and controlling costs. Meanwhile, the uniqueness of HEIs is based on a combination of different characteristics, namely the complexity of purpose, limited measurability of outputs, autonomy and dependency from wider society, a diffuse structure of authority and internal fragmentation. In addition, HEIs are fundamentally different from business organizations due to their unique decision-making processes, where each executive member is capable of independent decision-making and behavior [50, 65]. Further, HEIs are generally more resistant to change than business corporations due to the loosely coupled and autonomously operating administrative and academic units [25]. Furthermore, Bologa et al. [66] pointed out that the communication in HEIs is more difficult than in companies due to the large number of very different groups with different interests and objectives in different fields; thus, there are no clear formal communication structures in HEIs. The characteristics that make HEIs different require a distinct project management approach.

The main advantages of implementing an ERP system in HEIs are as follows: lower business risks; improved services for the faculty, students, and employees; increased income and decreased expenses due to improved efficiency; and improved information access for planning, organizing, and managing the institution where different departments share an integrated database [67]. Furthermore, Sabau et al. [68] introduced many ERP benefits for universities in terms of business and technical viewpoints.

The business benefits include:

- Campus-wide integration of a conventional system.

- Enhanced internal communications.

- Reduction or elimination of manual processes.

- Improved strategic decision making and planning capabilities.

- Self-service environment for students and faculty.

- Higher availability of administrative systems.

- Support of sophisticated and advanced data analyses for use in decision making.

- Integrated workflow for the industry's best practices and decreased dependence on paper.

The technical benefits include:

- Decrease or eliminated need for backup systems.

- Platform for re-engineering business practices and continued process enhancements.

- Maintenance and development of consistent data definitions.

- Accessible, user-friendly administrative and student support services.

- Increased data integrity, reliability, and validity.

- Guaranteed system-wide security and protection of confidential information.

- More seamless integration between technology and education delivery by providing a single platform based on new technologies and access to data in real time.

Nevertheless, a limited number of integral ERP solutions have been implemented in HEIs, and there is a need to introduce such ERP systems. Still, the risks related to the implementation of ERP systems in HEIs are relatively high due to the high degree of complexity [63]. According to Pollock and Cornford, ERP systems are "refashioning the identity of universities and accompanied by tensions in which ever site it is implemented" [50, p. 32]. Therefore, the implementation of these systems in the HEI sector is raising new organizational issues [69]. These systems were initially designed for the corporate sector, with little effort to make them fit universities' business processes; consequently, they either adjust the universities business 
processes to fit the ERP system or customize the ERP system to fit the universities' business processes [66]. In addition, Davison [71] identified cultural differences from that of North America through a case study on a Hong Kong University's implementation of an ERP system, including beliefs concerning providing access to information and miscommunication and difficulties in reengineering organizational processes. A number of researches have shown a high failure rate in the implementation of ERP systems; for instance, Cleveland State University (1998) took legal action against the ERP vendor when they found their new system could handle only half of their transaction volume. The university continued with the implementation of ERP despite rising costs, with a final cost of $\$ 15$ million, which exceeded the initial forecast by $\$ 10.8$ million. Likewise, ERP implementation costs for Ohio State University rose from an initial planned amount of $\$ 53$ million to $\$ 85$ million. The University of Minnesota had a comparable experience when planned projected costs of $\$ 38$ million finally reached $\$ 60$ million [72]. This illustrates the importance of minimizing ERP implementation failure in the HEI sector.

\section{RELATED WORK}

ERP systems have received substantial consideration in both academia and practice. Numerous research articles about ERP systems have been published, covering several topics and issues. Furthermore, a number of ERP literature reviews have been conducted [14, 26, 38, 45, 57, 73, $74,75,76,77]$ that provide an overview of existing ERP literature from varied perspectives.

Ngai et al. [14] reviewed 48 articles to illustrate the disparity between the 10 different countries/regions surveyed and the recommended empirical evidence for criticality of the 18 identified ERP success factors. The study results showed the most frequently cited critical factors for successful implementation of ERP systems are top management support, as well a straining and education. Moreover, a clear and defined project plan was another frequently cited factor in all the countries and regions.

In addition, Gargeya and Brady [38] identified six groups of factors leading to success in ERP implementation by reviewing published articles that reported SAP implementations in 44 companies from different industries based on conducting content analysis. The primary factors for successful implementation of SAP ERP projects include working with SAP functionality and maintaining scope and the cooperation of the project team/management support/consultants. Other success factors are the internal readiness/training, adequate system testing, organizational diversity, and planning/development/budgeting.

A comprehensive taxonomy of CSFs for ERP system implementation was presented by Dezdar and Sulaiman [45]. They analyzed the content of 95 articles publishedbetween 1999 and 2008; then, they arranged 17 identified ERP success factors using the frequency count method. They found that the most frequent CSFs include top management support and commitment, project management and evaluation, business process reengineering and minimum customization, ERP team composition, competence and compensation, and the change management program.

However, Finney and Corbett [57] recommended 26 CSFs based on the results of a comprehensive compilation and analysis of ERP implementation success factors, which they identified using content analysis and grouped into strategic and tactical categories. The study reveals that the five most significantly cited CSFs are top management commitment and support, change management, business process reengineering (BPR) and software configuration, training and job redesign, and the best and brightest project team. However, change management has emerged as the most widely cited CSF. 
Since ERP literature is a wide topic, we centered our review on ERP implementation in HEIs, which provide a more detailed analysis and deeper understanding of CSFs in ERP implementation within this sector. Abugabah and Sanzogni [11] collected critical literature reviews of the implications of ERP systems in HEIs, especially in Australia. The study shows that system users at all levels play a major role in defining the feasibility of ERP implementation. The researchers discuss the importance of establishing the requisite criteria to evaluate the performance of the system through the performance of its users after providing necessary training. It is important not to neglect other characteristics, such as technical and managerial aspects. The researchers stress the importance of aspects that influence the performance of staff, the quality of services provided, and the output of the system. Therefore, they try to gather the evaluation of ERP implementation while considering user and organization perspectives.

Furthermore, a study by Rabaa'i [28] concentrates on ERP implementation and evaluation, also in Australian HEIs. He discussed the CSFs identified by previous studies and their importance to answer the following research question: What are the key critical factors for ERP implementation success in a university environment? Based on a literature review, 12 CSFs for ERP implementation were identified using the frequency analysis. Change management and top management commitment and support are the most widely cited CSFs. Other factors include project management, business process reengineering and system customization, user training, cross-functional implementation teams, visioning and planning, consultant selection and relationship, an effective communication plan, ERP system selection, ERP systems integration, and post-implementation evaluation measures.

\section{RESEARCH METHODOLOGY}

The researchers conducted an extensive literature review, analyzing more than 50 articles published over a period of 13 years (2002-2015) to address the following question: ' What are the most imperative critical factors for ERP implementation success?' In this study, articles from journals, book chapters, conference proceedings, and dissertations were identified, analyzed, and classified. These articles were identified through a computer search of MIS journals and number of databases including Emerald, ScienceDirect, Proquest Computing, IEEE/Xplore, EBSCOhost, SpringerLink, ACM Digital Library and Google Scholar.

The articles were selected was based on the following search terms and keywords: "enterprise resource planning success factors,"“ERP implementation success,"“ERP implementation success in higher education institutions," "critical success factors for ERP implementation in higher education,"“critical success factors for enterprise systems,"“enterprise resource planning successful implementation,"“success factors of enterprise systems" and "CSFs of ERP system implementation in HEIs."

\section{SUCCESS FACTORS FOR ERP IMPLEMENTATION IN HEIs}

As mentioned above, an ERP redefines business operations and plays an important role in managing business processes in many organizations. In addition, there are many previously identified factors that could influence the successful implementation of ERP systems. Recently, universities have implemented ERP systems, but there is a lack of research focusing on the implementation of ERP systems in the HEI sector around the world [26, 29, 78, 79]. Furthermore, some studies have identified the urgent need to identify success factors that lead to the successful implementation of the system, as failure rate of ERP systems in HEIs is higher than that in the business sector $[11,30]$. 
Allen et al.[80] investigated the issues associated with ERP implementation via four in-depth case studies of HEIs in the UK that were in the process of implementing ERP systems to investigate whether the systems provided a feasible IS strategy for HEIs through interviews and reviews of secondary documentation. They adopted Pinto and Slevin's [54] and Holland et al.'s [81] CSF models, which include strategic issues and specify the need for a project mission, top management support, and project schedule outlining individual action steps for project implementation. Clearly, these issues are most important during the rollout of a project. Meanwhile, tactical elements such as communicating with all affected parties, recruiting the necessary technical and business specialists for the project team, obtaining the necessary underlying technology, user acceptance, and monitoring and feedback at each stage gain their importance in the implementation phase.

Chatfield [82] investigated the implementation factors that affect ERP system success in universities, including a decrease in implementation costs. The findings suggest that ERP system quality is improved by effectively training users, changing management, and providing support strategies for the users and the organization's culture. This requires involving university personnel in the implementation to reduce costs and making use of the personnel's existing knowledge of the organization.

Seo [12] in her thesis, focused on the challenges of ERP implementation in corporate and university environments by conducting two case studies to compare the similarities and differences, specifically between the Massachusetts Institute of Technology (MIT) and the Engineering Company (ENGCO). This research presents the top 12most frequently cited CSFs from previous studies. After evaluating these factors, the following CSFs were proven effective in the implementation of ERP in the university environment: change management, communication planning, ERP systems integration, and top management commitment and support. Moreover, Seo found that ERP failure results from the unique nature and decision support methodology of the university as well as the limited flexibility of university systems. The researcher also mentioned that university administration support in achieving the benefits of ERP systems could be the cornerstone for success, along with other success standards, such as team composition and strong communication across the organization.

Olugbara et al. [83] identified, validated, ranked and classified ERP success factors with reference to HEIs and described expert assessments to validate the relevance of the identified ERP success factors in the educational setting. Moreover, they used principal component analysis to reduce the dimensions and rank ERP success factors, as well as cross-impact analysis to classify ERP success factors. The study identified the following 10 CSFs influencing the effective implementation of ERP systems in African HEIs: top management support, management of expectations, business process reengineering, project team composition and competence, education and training of users, interdepartmental cooperation and communication, involvement of users in systems development and integration, culture of resistance within an organization, vendor and consultant support for users, and system changes and upgrades to new versions.

Somers and Nelson [84] developed a unified CSF model for industries in United States that described the importance of 22 CSFs identified across the stages of ERP implementation through responses from 86 organizations within variety of industries, including the education sector. The research sample targeted in the interviews and questionnaire consisted of senior-level IS executives. The authors identified and ranked the top five CSFs for ERP implementation as top management support, project team competence, inter-departmental cooperation, clear goals and objectives, and project management. Furthermore, the study suggested that the most important factor for executives is top management support. 
International Journal of Managing Information Technology (IJMIT) Vol.7, No.4, November 2015

Finally, Nah and Delgado [85] reviewed the literature to develop a comprehensive list of CSFs related to ERP implementation and upgrades. The researchers conducted two case studies at a university and a public company using interviews and questionnaires to collect data. They then organized the results into seven main categories. The results showed that the main factors involved in the successful implementation across the four phases of the ERP lifecycle are as follows: (1) a business plan and vision; (2) change management; (3) communication; (4) ERP team composition, skills, and compensation; (5) project management; (6) top management support and championship; and (7) system analysis, selection, and technical implementation.

\section{ERP IMPLEMENTATION WITH SAUDI HEIs}

With Saudi Arabia's orientation toward implementing e-government, whose significant benefits are attributable to the institutions and national economy of the Kingdom of Saudi Arabia, and due to government pressure to improve operational efficiency within their institutions, an egovernment program (Yesser) was established that enables the implementation of e-government and raising the public sector's productivity and efficiency [86]. Saudi HEIs began implementing ERP systems to increase their efficiency and to automate their administrative procedures. As major Saudi government institutions, HEIs have been strongly influenced by the government trend to adopt new technologies.

A few research studies on the implementation of the ERP system in Saudi HEIs have concentrated on general technical and users' perspectives [7, 30, 87]; these have been limited to study the experience of King Saud University (KSU) in ERP implementation. It should be noted that the ERP system of KSU is called MADAR; it is not an ERP global software system such as SAP, Microsoft Dynamics, or Oracle E-Business Suite (EBS); rather, it has been locally designed due to budget constraints, a shortage of skilled users, and the greater flexibility for customization with the governmental policies [88]. Therefore, the success factors and obstacles may differ from the experiences of other universities that have implemented global ERP software systems.

Al-Hudhaif [87] investigated the factors affecting the ERP implementation from the user's perspective at KSU. A theoretical framework was developed and four hypotheses were explained to look at the status of system implementation at this university. The results showed the total success is dependent on the user satisfaction. In addition, the researcher found a significant relationship between satisfaction level and challenges to implementation. He suggested that the commitment of university head administration in ERP adaptation plays the major role of success implementation. However, the study suggests no relationships between the training factor and success of ERP implementation.

Moreover, Aldayel et al. [30] conducted a case study for the CSFs of ERP implementation in higher education from technical and user perspective. Their case study had been conducted at KSU which implemented MADAR system. The results showed that the most important CSFs in ERP implementation from a technical point of view were project management and ERP system selection. Other factors included stakeholder participation, business process reengineering and customization, top management commitment and support, ERP team composition, ERP systems integration, choice of supplier and its support, scope of implementation, and consultant participation. From the user's perspective, the most important factor was training. 


\section{CSFs FOR ERP IMPLEMENTATION IN HEIs}

The results of the abovementioned research studies on the success factors of ERP implementation describe the problem complexity using a variety of approaches. The CSFs and the results of the research studies differed substantially, showing that the factors leading to success are complex and cannot occur in isolation. Indeed, they overlap and are hard to separate [38]. Some researchers have suggested that the CSFs of ERP implementation identified in the literature in terms of private sector organizations are equally applicable to organizations in the public sector. Furthermore, they pointed to additional CSFs in public sector organizations, where it is more difficult to successfully achieve ERP implementation. The government acquisition rules must be revised to align with the CSFs $[38,89,90]$; thus, CSFs need to be identified and adapted to the public sector.

The aim of this paper is to define the main important factors contributing to the success of ERP implementation in HEIs. Table 1 shows the 13 factors identified as critical to ERP implementation success from previous studies conducted in the HEIs sector.

Table1. The most important ERP CSFs extracted from the literature.

\begin{tabular}{|c|c|c|c|}
\hline \# & Factors & References & Definition \\
\hline 1 & $\begin{array}{l}\text { Top management } \\
\text { commitment and } \\
\text { support }\end{array}$ & $\begin{array}{l}{[25,28,29} \\
30,66,68 \\
70,75,83 \\
84,85]\end{array}$ & $\begin{array}{l}\text { There is enough support from senior } \\
\text { management in the ERP project. Top } \\
\text { management must be willing to be involved and } \\
\text { commit to allocating valuable resources to the } \\
\text { implementation effort. }\end{array}$ \\
\hline 2 & $\begin{array}{l}\text { Change } \\
\text { management }\end{array}$ & $\begin{array}{l}{[25,28,29} \\
30,66,68 \\
70,75,83 \\
84,85]\end{array}$ & $\begin{array}{l}\text { A primary strategy, strong institutional identity } \\
\text { and structured approach are needed to create a } \\
\text { comprehensive environment to ensure the } \\
\text { successful implementation and smooth } \\
\text { transitioning to the ERP system. }\end{array}$ \\
\hline 3 & $\begin{array}{l}\text { Project } \\
\text { management }\end{array}$ & $\begin{array}{l}{[25,28,29} \\
30,66,68 \\
70,75,83 \\
84,85]\end{array}$ & $\begin{array}{l}\text { Effective management of the ERP project, } \\
\text { including defining the project scope, goals, } \\
\text { objectives, schedule and strategy and careful } \\
\text { tracking of ERP project progress to plan, } \\
\text { coordinate and monitor various defined } \\
\text { activities in different stages of ERP } \\
\text { implementation. }\end{array}$ \\
\hline 4 & Project champion & $\begin{array}{l}{[66,70,84,} \\
85]\end{array}$ & $\begin{array}{l}\text { A project leader who plays a critical role in the } \\
\text { implementation of ERP and makes the project } \\
\text { work by setting goals and effecting legitimate } \\
\text { changes. }\end{array}$ \\
\hline 5 & $\begin{array}{l}\text { System } \\
\text { customization }\end{array}$ & $\begin{array}{l}{[25,28,29} \\
30,70,84 \\
85]\end{array}$ & $\begin{array}{l}\text { Modification of the ERP package according to } \\
\text { the institution's needs to fit its existing business } \\
\text { process. }\end{array}$ \\
\hline 6 & $\begin{array}{l}\text { Business process } \\
\text { reengineering } \\
(\mathrm{BPR})\end{array}$ & $\begin{array}{l}{[25,28,29} \\
30,66,70,75 \\
83,84,85]\end{array}$ & $\begin{array}{l}\text { Changes in the work process that arise with ERP } \\
\text { system implement on to fit and adapt the } \\
\text { functionality of the system package instead of } \\
\text { trying to modify the ERP system to fit the } \\
\text { organization's current business processes. }\end{array}$ \\
\hline 7 & ERP & {$[25,28,30$,} & The team should consist of the best, most skilled \\
\hline
\end{tabular}


International Journal of Managing Information Technology (IJMIT) Vol.7, No.4, November 2015

\begin{tabular}{|c|c|c|c|}
\hline$\#$ & Factors & References & Definition \\
\hline & $\begin{array}{l}\text { implementation } \\
\text { team }\end{array}$ & $\begin{array}{l}66,68,70 \\
83,84,85]\end{array}$ & $\begin{array}{l}\text { people in the institution. Necessary capabilities } \\
\text { include team leadership, cross-functional team } \\
\text { representation from all business units and strong } \\
\text { commitment to the implementation duties. }\end{array}$ \\
\hline 8 & $\begin{array}{l}\text { Consultant } \\
\text { selection and } \\
\text { relationship }\end{array}$ & $\begin{array}{l}{[28,30,66} \\
70,75,83 \\
84,85]\end{array}$ & $\begin{array}{l}\text { The extent to which ERP consultants who are } \\
\text { expert and knowledgeable about the installation } \\
\text { are part of the implementation process. It is } \\
\text { important to arrange for knowledge transfer } \\
\text { from the consultant to the project manager and } \\
\text { staff. }\end{array}$ \\
\hline 9 & $\begin{array}{l}\text { Effective } \\
\text { communication } \\
\text { plan }\end{array}$ & $\begin{array}{l}{[25,28,29} \\
66,68,70 \\
75,83,84 \\
85]\end{array}$ & $\begin{array}{l}\text { Covering and sharing information, scope, } \\
\text { activities and objectives between the ERP } \\
\text { project team members and communication of } \\
\text { the results and goals at each ERP } \\
\text { implementation stage to the rest of the } \\
\text { institution. }\end{array}$ \\
\hline 10 & $\begin{array}{l}\text { Active partnership } \\
\text { with vendor }\end{array}$ & $\begin{array}{l}{[25,30,70} \\
75,83,84 \\
85]\end{array}$ & $\begin{array}{l}\text { Support ranging from technical assistance to } \\
\text { training that can reduce the cost of } \\
\text { implementation; the organization cam gain other } \\
\text { benefits from partnerships with the vendor and } \\
\text { use the vendor's customization tools. }\end{array}$ \\
\hline 11 & $\begin{array}{l}\text { ERP system } \\
\text { selection }\end{array}$ & $\begin{array}{l}{[28,29,30} \\
68,70,78 \\
83,84,85]\end{array}$ & $\begin{array}{l}\text { Careful ERP software package selection that } \\
\text { matches the organizational needs, business } \\
\text { processes and practices. }\end{array}$ \\
\hline 12 & System integration & {$[28,30,85]$} & $\begin{array}{l}\text { Good integration between the ERP system and } \\
\text { other systems in the institution to smoothly } \\
\text { share and transfer information. }\end{array}$ \\
\hline 13 & $\begin{array}{l}\text { Post- } \\
\text { implementation } \\
\text { evaluation and } \\
\text { management }\end{array}$ & {$[28,70]$} & $\begin{array}{l}\text { All projects require some kind of post- } \\
\text { evaluation through the exchange of information } \\
\text { between the project manager and project team } \\
\text { members and analysis of user feedback. }\end{array}$ \\
\hline
\end{tabular}

\section{CONCLUSION}

This paper gave a general overview of the implementation of ERP systems, including definitions, motivations for adopting ERP systems, and their challenges. Furthermore, it explained the CSFs concept and provided a comprehensive overview of the literature on ERP implementation success factors.

This research reviewed the previous literature on ERP implementation with a focus on success factors for ERP system implementation in the HEI sector worldwide and in Saudi Arabia. The aim of this was to fill the gap in research regarding the implementation of the ERP system in this sector, particularly since the failure rate of ERP systems in HEIs is higher than that in the business sector. This paper identified and defined the 13 most important ERP CSFs extracted from previous studies in this field.

This research is considered as a starting point to conduct in-depth analysis of CSFs in HEIs to increase the success rate of ERP implementation. Furthermore, it will enrich the academic knowledge in this field because of the lack of previous research on the successful implementation 
International Journal of Managing Information Technology (IJMIT) Vol.7, No.4, November 2015

of ERP systems in the HEI sector. The researchers intend to carry on the reach by conducting indepth analysis of different universities in Saudi Arabia that have implemented an ERP system.

\section{REFRENCES}

[1] Ifinedo, Princely (2011) "Examining the Influences of External Expertise and In-House Computer/IT Knowledge on ERP System Success",Journal of Systems and Software Vol. 84 No. 12, pp. 20652078.

[2] Klaus, Helmut., Rosemann, Michael \& Gable, Guy (2000) "What is ERP?", Information systems frontiers Vol. 2, No.2, pp. 141-162.

[3] Mabert, VincentA., Sony, Ashok \& Venkataramanan, Munirpallam (2003) "The Impact of Organization Size on Enterprise Resource Planning (ERP) Implementations in the US Manufacturing Sector", Omega 31(3), pp. 235-246.

[4] Wang, Eric T.G., Shih, S.P.\& Jiang, J.J. \& Klein, G. (2008) "The Consistency among Facilitating Factors and ERP Implementation Success: A Holistic View of Fit". Journal of Systems and Software Vol. 81, No. 9, pp. 1609-1621.

[5] Xu, LauraXiao Xia., Yu, Wang Feng, Lim, Roland \& Hock, Lua Eng (2010) "A Methodology for Successful Implementation of ERP in Smaller Companies", In: 2010 IEEE International Conference on Service Operations and Logistics and Informatics (SOLI).Qingdao, China, pp. 380-385.

[6] Siriginidi, Subba Rao (2000) "Enterprise Resource Planning in Reengineering Business",Business Process Management Journal,Vol. 6, No. 5, pp. 376-391.

[7] Al-Shamlan, Hala M. \& Al-Mudimigh, Abdullah S. (2011)"The Change Management Strategies and Processes for Successful ERP Implementation: A Case Study of MADAR", International Journal of Computer Science,Vol. 8, No. 2, pp. 399-407.

[8] Liang, Huigang., Saraf, Nilesh., Hu, Qing. \& Xue,Yajiong (2007) "Assimilation of Enterprise Systems: The Effect of Institutional Pressures and Mediating Role of Top Management", MISQuarterly, Vol. 31, NO. 1, pp. 59-87.

[9] Martin, M.H. (1998). "An ERP strategy". Time Inc., New York 137, PP. 95-97.

[10] Samuel, R. Dhinakaran \& Kumar, Santhosh (2013) "Prediction of ERP Success Before the Implementation", In:International Asia Conference on Industrial Engineering and Management Innovation (IEMI2012), Proceedings. Springer Berlin Heidelberg, pp. 219-227.

[11] Abugabah, Ahed \& Sanzogni, Louis (2010) "Enterprise Resource Planning (ERP) System in Higher Education:A Literature Review and Implications", International Journal of Human and Social Sciences, Vol. 5, NO. 6, pp. 395-399.

[12] Seo, Goeun (2013) "Challenges in Implementing Enterprise Resource Planning (ERP) System in Large Organizations: Similarities and Differences Between Corporate and University Environment", Master's thesis, Massachusetts Institute of Technology

[13] Al-Mashari, Majed., Al-Mudimigh, Abdullah. \& Zairi, Mohamed (2003) "Enterprise Resource Planning: A Taxonomy of Critical Factors",European journal of operational research,Vol.146, No. 2, pp. 352-364.

[14 ]Ngai, Eric. WT., Law, Chuck CH\& Wat \& Francis KT (2008) "Examining the Critical Success Factors in the Adoption of Enterprise Resource Planning",Computers in Industry,Vol.59, No. 6, pp. 548-564.

[15] Zhang ,Zhe., Lee,Matthew K.O., Huang, Pei., Zhang, Lliang. \&Huang, Xiaoyuan (2005) "A Framework of ERP Systems Implementation Success in China:An Empirical Study", International Journal of Production Economics, Vol. 98, No. 1, pp. 56-80.

[16] Bhatti, T. R. (2005) "Critical Success Factors for the Implementation of Enterprise Resource Planning (ERP): Empirical Validation", In:2nd International Conference on Innovation in Information Technology IIT press, Dubai, UAE, pp. 1-10.

[17] Holland Christopher P. \& Light, Ben (1999) "ACritical Success Factors Model for ERP Implementation", IEEE software, Vol. 16, No. 3, pp. 30-36.

[18] Jafari, S.M., Osman, M.R., Yusuff, R.M. \&Tang, S.H. (2006) "ERP Systems Implementation in Malaysia:Importance of Critical Success Factors", International Journal of Engineering and Technolog, Vol. 3, No.1, pp. 125-131. 
International Journal of Managing Information Technology (IJMIT) Vol.7, No.4, November 2015

[19] Kamhawi, Emad .M. (2007) "Critical Factors for Implementation Success of ERP Systems: An Empirical Investigation from Bahrain",International Journal of Enterprise Information Systems, Vol. 3, No. 2, pp. 34-49.

[20] Liu, Pang-Lo (2011) "Empirical Study on Influence of Critical Success Factors on ERP Knowledge Management on Management Performance in High-Tech Industries in Taiwan",Expert Systems with Applications, Vol.38, No. 8, pp.10696-10704.

[21] Loh, Tee Chiat\& Koh, S.C.L. (2004) "Critical Elements for a Successful Enterprise Resource Planning Implementation in Small- and Medium-Sized Enterprises",International journal of production research, Vol. 42, No. 17, pp. 3433-3455.

[22] Motwani, Jaideep., Subramanian, Ram. \& Gopalakrishna, Pradeep (2005) "Critical Factors for Successful ERP Implementation: Exploratory Findings from Four Case Studies", Computers in Industry, Vol. 56, No. 6, pp. 529-544.

[23] Soja, Piotr (2006) "SuccessFactors in ERP Systems Implementations: Lessons from Practice", Journal of enterprise information management, Vol. 19, No. 6, pp.646--661.

[24] Umble,Elisabeth J., Haft, Ronald. R. \& Umble Michael M. (2003) "EnterpriseResource Planning: Implementation Procedures and Critical Success Factors", European journal of operational research , Vol. 146, No. 2, pp.241-257.

[25] Gates, Kathryn F. (2004) "Evaluating the North American Pilot for SAP's Campus Management System", In von Hellens, L., Nielsen, S., Beekhuyzen, J. (eds.), Qualitative Case Studies on Implementation of Enterprise Wide Systems. Idea Group, Hershey, pp. 192-210.

[26] Moon, Young B. (2007) "Enterprise Resource Planning (ERP): AReview of the Literature", International Journal of Management and Enterprise Development, Vol. 4, No. 3, pp. 235-264.

[27] Nielsen, Jens L. (2005) "Critical Success Factors for Implementing ERP System", In von Hellens, L., Nielsen, S., Beekhuyzen, J. (eds.), Qualitative case studies on implementation of enterprise wide systems. Idea Group, Hershey, pp. 211-231.

[28] Rabaa'i, Ahmad A. (2009) "Identifying Critical Success Factors of ERP Systems at the Higher Education Sector",In: ISIICT2009: Third International Symposium on Innovation in Information \& Communicaton Technology, Philadelphia Uni., Amman, Jordan .

[29] Ahmad, Raja Lope, Othman, Zulkifli \& Mukhtar, Mohsin (2011) "ERP Implementation Framework for Malaysian Private Institution of Higher Learning", In:2011 International Conference on Electrical Engineering and Informatics (ICEEI), Bandung, Indonesia, pp. 1-5.

[30] Aldayel, AbeerI., Aldayel, Mashael S. \& Al-Mudimigh, Abdullah S. (2011) "The Critical Success Factors of ERP Implementation in Higher Education in Saudi Arabia: A Case Study", journal of Information Technology \& Economic Development, Vol. 2, No, 2, pp. 1-16.

[31] Ministry of Higher Education, (2015) [Online]. Available:http://he.moe.gov.sa/ar/about/egovinitiaves/Pages/cInitiatives.aspx

[32] Gable, Guy G. (1998) "Large Package Software-A Neglected Technology?", Journal of Global Information Management, Vol.6, pp. 3-4.

[33] Rosemann, Michael \& Wiese, Jens (1999) "Measuring the Performance of ERP Software-A Balanced Scorecard Approach", In:10th Australasian Conference on Information Systems, Wellington, New Zealand, pp. 733-784.

[34] Huang, Albert, Yen, David C., Chou, David C. \& Xu, Yurong (2003) "Corporate Applications Integration: Challenges, Opportunities, and Implementation Strategies",Journal of Business and Management,Vol. 9 No. 2, pp. 137-145.

[35] Rashid, MohammadA., Hossain, Liaquat \& Patrick, Jon David (2002) "The Evolution of ERP Systems: A Historical Perspective", In L. Hossain, J. Patrick, \& M. Rashid, Enterprise Resource Planning: Global Opportunities \& Challenges, Idea Group, United States of America, pp. 1--16.

[36] Beheshti, Hooshang. M. (2006) "What Managers Should Know about ERP/ERP II", Management Research News ,Vol. 29 No. 4, pp.184--193.

[37] Chang, Man-Kit., Cheung, Waiman., Cheng, C. Hung \& Yeung, Jeff H.Y. (2008) "Understanding ERP System Adoption from the User's Perspective", International Journal of Production Economics, Vol. 113, No. 2, pp. 928--942.

[38] Gargeya, Vidyaranya B. \&Brady, Cydnee (2005) "Success and Failure Factors of Adopting SAP in ERP System Implementation", Business Process Management Journal,Vol.11, No. 5, pp. 501-516.

[39] Luo, Wenhong \& Strong, Diane. (2004) "A Framework for Evaluating ERP Implementation Choices", Engineering Management, IEEE Transactions,Vol. 51, No. 3, pp. 322-333. 
International Journal of Managing Information Technology (IJMIT) Vol.7, No.4, November 2015

[40] Spathis, Charalambos \& Ananiadis, John (2005) "Assessing the Benefits of Using an Enterprise System in Accounting Information and Management", Journal of Enterprise Information Management, Vol. 18, No. 2, pp.195-210.

[41] Nah, Fui-Hoon Fiona, Lau, Janet Lee-Shang \& Kuang, Jinghua (2001) "CriticalFactors for Successful Implementation of Enterprise Systems", Business process management journal, Vol. 7, No. 3, pp. 285-296.

[42] Poston, Robin \& Grabski, Severin (2001) "Financial Impacts of Enterprise Resource Planning Implementations", International Journal of Accounting Information Systems, Vol. 2, No. 4, pp. 271294.

[43] Shang, Shari \& Seddon, Peter B. (2000) "A Comprehensive Framework for Classifying the Benefits of ERP Systems", In: Proceedings of AMCIS 2000, Long Beach, CA, pp. 1005-1014.

[44] Shang, Shari \& Seddon, Peter B. (2002) "Assessing and Managing the Benefits of Enterprise Systems: The Business Manager's Perspective", Information systems journal, Vol. 12, No. 4, pp. 271-299.

[45] Dezdar, Shahin \& Sulaiman, Ainin (2009) "Successful Enterprise Resource Planning Implementation: Taxonomy of Critical Factors", Industrial Management \& Data Systems, Vol. 109, No. 8, pp. 10371052.

[46] Xue, Yajiong, Liang, Huigang., Boulton, William R. \& Snyder, Charles A. (2005) "ERP Implementation Failures in China: Case Studies with Implications for ERP Vendors",International journal of production economics, Vol. 97, No. 3, pp.279-295.

[47] Traci, Barker \& Mark, N. Frolick (2003) "ERP Implementation Failure: A Case Study", Information Systems Management,Vol. 20, No. 4, pp. 43-49.

[48] Chen, Charlie C., Law, Chuck \& Yang, Samuel C. (2009) "Managing ERP Implementation Failure: A Project Management Perspective",Engineering Management IEEE Transactions, Vol. 56, No. 1, pp. 157-170.

[49] Markus, M. Lynne, Axline, Sheryl., Petrie, David \& Tanis, S. Cornelis. (2000) "Learning from Adopters' Experiences with ERP:Problems Encountered and Success Achieved", Journal of information technology, Vol. 15, No. 4, pp. 245-265.

[50] Pollock, Neil \& Cornford, James (2004) "ERP Systems and the University as a "Unique"Organisation", Information technology \& people, Vol. 17, No. 1, pp.31-52.

[51] Markus, M. Lynne \& Tanis, Cornelis (2000) "The Enterprise Systems Experience-From Adoption to Success", Framing the domains of IT research: Glimpsing the future through the past 173, pp. 207173.

[52] Rockart, John F. (1978) "Chief Executives Define Their Own Data Needs", Harvard business review, Vol. 57, No. 2, pp. 81-93.

[53] Rockart, John F. \& Bullen, Christine V. (1986) "The Rise of Managerial Computing: The Best of the Center for Information Systems Research", Dow Jones-Irwin, New York.

[54] Pinto, Jeffrey K. \& Slevin, Dennis P. (1987) "Critical Factors in Successful Project Implementation", Engineering Management, IEEE Transactions on 1, Vol. 34, No. 1, pp. 22-27.

[55] Shanks, G., Parr, A.,Hu, B., Corbitt, B., Thanasankit, T.\& Seddon, P. (2000) "Differences in Critical Success Factors in ERP Systems Implementation in Australia and China: A Cultural Analysis",In: Proceedings of ECIS 2000, Vienna, Austria, pp. 537-544.

[56] Somers, Toni M. \& Nelson, Klara G. (2004) "A Taxonomy of Players and Activities Across the ERP Project Life Cycle", Information \& Management, Vol. 41, No. 3, pp. 257-278.

[57] Finney, Sherry \& Corbett, Martin (2007) "ERP Implementation: A Compilation and Analysis of Critical Success Factors", Business Process Management Journal, Vol. 3, No. 3, pp.329-347.

[58] Capaldo G., \& Rippa, P. (2009) "A planned oriented approach for EPR implementation strategy selection". Journal of Enterprise Information Management, 22(6), pp. 642-659.

[59] Hasibuan, Z. A., \& Dantes, G. R. (2012) "Priority of Key Success Factors (KSFS) on Enterprise Resource Planning (ERP) System Implementation Life Cycle". Journal of Enterprise Resource Planning Studies, 2012, pp.1-15.

[60] Kronbichler, S. A., Ostermann, H., Rol, R., \& Staudinger, S. (2009) "A review of critical success factors for ERP-projects". Open Information Systems Journal, 3, pp. 14-25.

[61] Motwani, J., Subramanian, R., \& Gopalakrishna, P. (2005) "Critical factors for successful ERP implementation: exploratory findings from four case studies". Computers in Industry, 56(6), pp. 529544. 
International Journal of Managing Information Technology (IJMIT) Vol.7, No.4, November 2015

[62] Thomas, Glenn A. \& Jajodia, Shyam (2004) "Commercial-Off-the-Shelf Enterprise Resource Planning Software Implementations in the Public Sector: Practical Approaches for Improving Project Success", The Journal of Government Financial Management, Vol. 53, No. 2, pp.12--19.

[63] Zornada, Leo \& Velkavrh, TamaraBertok (2005) "Implementing ERP Systems in Higher Education Institutions",In: 27th International Conference on Information Technology Interfaces ICTI, Cavtat, Croatia.

[64] Lockwood, G. (1985) "Universities as Organizations", In Lockwood, G. and Davies, J. (eds), Universities; The Management Challenge, Windsor, UK., pp. 139-163.

[65] Heiskanen, Ari., Newman, Michael\& Similä, Jouni (2000) "The Social Dynamics of Software Development", Accounting, Management and Information Technologies, Vol. 10, No. 1, pp. 1-32.

[66] Bologa, Razvan., Bologa, Ana-Ramona \& Sabau, Gheorghe (2009) "Success Factors for Higher Education ERPs",International Conference on Computer Technology and Development, pp. 28-32.

[67] King, Paula., Kvavik, Robert B. \& Voloudakis, J. (2002) "Enterprise Resource Planning Systems in Higher Education",EDUCAUSE Center for Applied Research: Research Bulletin 22, pp. 1-11.

[68] Sabau, G., Munten, M., Bologa, A. R., Bologa, R. \& Surcel, T. (2009) "An Evaluation Framework for Higher Education ERP Systems", WSEAS Transactions on Computers, Vol. 8, No. 11, pp. 17901799.

[69] Beekhuyzen, J., Goodwin, M., Nielsen, J.L. \& Uervirojnangkoorn, M. (2001) "ERP Implementation at Australian Universities", Technical Report, Brisbane, Australia, Griffith University.

[70] von Hellens, Liisa, Nielsen, Sue \& Beekhuyzen, Jenine (2005) "Qualitative Case Studies on Implementation of Enterprise Wide Systems", IGI Global, Hershey.

[71] Davison, Robert. (2002) "Cultural Complications of ERP", Communications of the ACM,Vol. 45, No.7, pp.109-111.

[72] Parth, Frank R., Gumz, J. (2003) "Getting Your ERP Implementation Back on Track".

[73] Addo-Tenkorang, Richard \& Helo, Petri (2011) "Enterprise Resource Planning (ERP): A Review Literature Report",Proceedings of the World Congress on Engineering and Computer Science, San Francisco, CA, Vol IIpp19-21.

[74] Asemi, Asefeh \& Jazi, Mohammad (2010) "A Comparative Study of Critical Success Factors (CSFs) in Implementation of ERP in Developed and Developing Countries",International Journal, Vol. 2, No.5, pp99-110.

[75] Esteves, Jose \& Bohórquez, Victor (2007) "An updated ERP systems annotated bibliography: 20012005", Instituto de Empresa Business School. Working Paper No. WP, Vol. 7, No. 4M pp 2-59.

[76] Shehab, Essam, Sharp,Supramaniam \& Spedding (2004) "Enterprise resource planning: An integrative review",Business Process Management Journal, Vol. 10, No. 4, pp359-386.

[77] Botta-Genoulaz, Valerie, Millet, Pierre-Alain \& Grabot, Bernard (2005) "A survey on the Recent Research Literature on ERP Systems", Computers in Industry, Vol. 56, No. 6, pp510-522.

[78] Rabaa'i, Ahmad A., Bandara, Wasana \& Gable, Guy (2009) "ERP Systems in the Higher Education Sector: ADescriptive Study",In:Proceedings of the 20th Australasian Conference on Information Systems, Monash Uni.: Caulfield Campus, Melbourne, Australia, pp. 456-470.

[79] AlQashami, Ashwaq \& Mohammad Heba (2015) "Critical Success Factors (CSFs) of Enterprise Resource Planning (ERP) System Implementation in Higher Education Institutions (HEIs): Concepts and Literature Review", In Computer Science \& Information Technology, Jan Zizka, Dhinaharan Nagamalai (eds.), Fourth International Conference on Advanced Information Technologies and Applications (ICAITA 2015), Dubai, UAE, pp. 81-98.

[80] Allen, David., Kern, Thomas \& Havenhand, Mark (2002) "ERP Critical Success Factors: An Exploration of the Contextual Factors in Public Sector Institutions", In:Proceedings of the 35th Annual Hawaii International Conference on System Sciences(HICSS), Hawaii,U.S.A, pp. 3062-307.

[81] Holland, Christoper P., Light, Ben \& Gibson, Nicola (1999) "A Critical Success Factors Model for Enterprise Resource Planning Implementation", Proceedings of the 7th European Conference on Information Systems, Vol. 1, pp. 273-287.

[82] Chatfield, Craig (2005) "Factors that Affect ERP System Success",Qualitative Case Studies on Implementation of Enterprise Wide Systems,L. von Hellens,S. Nielsen, \& J. Beekhuyzen,Eds.Hershey, Pennsylvania: IGI, pp232-242.

[83] Olugbara, O.O., Kalema, B.M. \& Kekwaletswe, R.M. (2014) "Identifying Critical Success Factors: The Case of ERP Systems in Higher Education", The African Journal of Information Systems, Vol. 6, No. 3, pp. 65-84. 
[84] Somers, Toni M. \& Nelson, Klara (2001) "The Impact of Critical Success Factors Across the Stages of Enterprise Resource Planning Implementations",In Proceedings of the 34th Annual Hawaii International Conference on System Sciences, Maui, Hawaii, pp. 1-10.

[85] Nah, F.F.H. \& Delgado, Santiago (2006) "Critical Success Factors for Enterprise Resource Planning Implementation and Upgrade", Journal of Computer Information Systems , Vol. 46, No. 5, pp. 99113.

[86] E-Government Program http://www.yesser.gov.sa/en/ProgramDefinition/Pages/Overview.aspx

[87] Al-Hudhaif, Sulaiman A. (2012) "ERP Implementation at King Saud University". Global Journal of Management and Business Research,Vol. 12, No. 5, pp. 71-77.

[88] Alghathbar, Khaled (2008) "Practical ERP Implementation in Government Organization",International Conference on E-Learning, E-Business, Enterprise Information Systems, and E-Government, Las Vegas, USA, pp. 343-349.

[89] Frye, Doug., Gulledge, T., Leary, M. \& Sommer, R. (2007) "PublicSector Enterprise System Implementation", Electronic Government, An International Journal, Vol. 4, No. 1, pp. 76-96.

[90] Rabaa'i, Ahmad A. (2009) "The Impact of Organisational Culture on ERP Systems Implementation: Lessons from Jordan", In:Proceedings of the Pacific Asia Conference on Information Systems (PACIS 2009), Hyderabad, India.

\section{Authors}

Ashwaq Sulaiman AlQashami earned her bachelor degree with a specialization in Information Systems at the College of Computer and Information Sciences at Al-Imam Muhammad Ibn Saud University in Riyadh, Saudi Arabia, in 2010. She is currently pursuing a master's degree from the same department with an expected graduation date in 2016. She has Six years of experience in both public and private sectors in systems analysis, quality assurance and training. Currently, she is working as a programmer at Princess Nora University. Her current research interests include enterprise information systems, information technology governance and project management.

Heba Mohammad is an Assistant Professor of Information Systems at the College of Computer and Information Sciences of Al-Imam Muhammad Ibn Saud University. She received her Ph.D in e-business from University of Salento, Italy. Her research focuses on enterprise systems, knowledge management, communities of practice, e-business and e-learning. She also provides different consultation services to various institutions. 